\title{
定着用膨張材による連続䋊維緊張材の 定着法に関する研究
}

\author{
原田哲夫 1 - 出光 隆 $2 \cdot M y o \mathrm{Khin}^{3}$ - 副田孝一 4 ・渡辺 明 5
}

\author{
${ }^{1}$ 正会員 工博 長崎大学教授 工学部構造工学科 （テ852-8521 長崎市文教町 1-14） \\ 2 フェロー 工博 九州工業大学教授 工学部建設社会工学科 （†804-8550 北九州市戸畑区仙水町 1-1） \\ 3 正会員 工修 第一工業大学助教授 工学部土木工学科 （テ899-4395 国分市中央 1-10-2） \\ 4 正会員 博士（工学）太平洋セメント株式会社 佐倉研究所（テ285-8655 佐倉市大作 2-4-2） \\ 5 フェロー 工博 九州共立大学教授 工学部開発学科（テ807-8585 北九州市八幡西区自由ヶ丘 1-8）
}

\begin{abstract}
連続絨維補強材を緊張材として用いる場合，あるいは引張試殹を実施する場合には，その定着方法が最も重 要である. 筆者らは, 膨張圧が $50 \mathrm{MPa}$ 以上の高膨張圧を発生し、しかも圧力伝播が液压的である定着用膨張材 を用いる定着方法を開発した. 必要定着長と膨張圧の関係, ポストテンション方式の定着具として必要な長期 安定性や疲労特性等を実験的に検討するとともに，マルチケーブルとしての特長についても言及した.
\end{abstract}

Key Words : FRP tendon, highly expansive material, anchoring system, prestressed concrete

\section{1.まえがき}

カーボン繊維, アラミド繊維などの連続繊維からな る連続纎維補強材をコンクリート構造物へ適用する研 究が盛んに行われてきており,すでに土木学会から「連 続纎維補強材を用いたコンクリート構造物の設計・施 工指針（案）」が出版されてている1).

連続瀻維補強材をP C 緊張材として用いる場合に, 最も重要なのは定着方法をどのように行うかである. 連続纎維緊張材は一般に一方向性材で，局部的な支正 やせん断に対して弱いため, PC 鋼材と同様の定着が 困難であって, 種々の工夫を施したいくつかの定着方 法が開発されている. しかしながら, 定着効率, 現場 施工性，コスト面のすべてに満足のいく方法は見あた らないように思われる．そこで，筆者らは静的破砕剤 の 50MPa 以上に達する高嘭張圧, しかも膨張圧は液 圧的に作用するという性質を利用した，より簡便な連 続繊維緊張材用の定着方法を開発した ${ }^{2)}$.

本論では，静的破砕剂之静的破哗剂をべースに充媜 性, 材料分離抵抗性および膨張圧の発現時間の観点か ら定着用に改良されたいわゆる「定着用膨張材」(Highly Expansive Material (HEM))を用いて行った定着法として の基礎的な研究について述べるものである. すなわち,
主として本定着法をポストテンション工法, 外ケーブ ル工法の定着法として用いる場合に必ず解決しておか なければならない問題であるところの必要定着長と脵 張圧の関係，長期の安定性，そして疲労特性等の基礎 的な事項についての検討を行った．さらに，本定着法 を用いたマルチケーブル定着法についても言及した.

上記の各項目については，これまで講演論文，国際 会議やシンポジウムの概要集等に部分的に公表してき てはいるが 3， 4)，ク，本論文では，さらにその後の新 たな研究成果を追加し，本定着法開発の経緯から実用 化・適用に至る各過程での理論的実験的検討結果を総 合的にかつ系統的に示している. また，本定着法は連 続繊維緊張材を用いた「グラウンドアンカー工法」へ も適用され，実用化が図られているがの，第4 章に示 す 7 年以上に渡る長期実験の結果は，永久アンカーエ 法の成否を占う上で極めて有用であると考える。

なお，定着用膨張材に関してはさらに広箐多岐な応 用が期待されるので，本論文では，今後の可能性や付 随する問題点などにも触れており，それらも含めたこ れまでの基礎的研觉成果が, 各方面でのさらなる研觉 展開のために資することを切に願いたい．

ちなみに，本定着法は通常のP ( 鋼材を緊張状態の) まま途中定着する, いわゆる「中間定着工法」への適 
表一 1 化学組成

\begin{tabular}{|c|c|c|c|c|c|c|c|c|c|c|}
\hline & \multicolumn{9}{|c|}{ 化学成分 (mass\%) } & \multirow{2}{*}{$\begin{array}{c}\text { プレーン比表面積 } \\
\left(\mathrm{cm}^{2} / \mathrm{g}\right)\end{array}$} \\
\hline & Ig.loss & $\mathrm{SiO}_{2}$ & $\mathrm{Al}_{2} \mathrm{O}_{3}$ & $\mathrm{Fe}_{2} \mathrm{O}_{3}$ & $\mathrm{CaO}$ & $\mathrm{MgO}$ & $\mathrm{SO}_{3}$ & 計 & $\mathrm{f}-\mathrm{CaO}$ & \\
\hline 定着用膨張材 $\mathrm{A}$ & 1.5 & 8.0 & 1.9 & 0.9 & 83.5 & 0.6 & 3.4 & 99.8 & 56.1 & 3040 \\
\hline 定着用膨張材B & 1.6 & 8.8 & 2.3 & 1.3 & 81.5 & 0.4 & 3.8 & 99.7 & 52.2 & 2010 \\
\hline 静的破砕剤 & 1.2 & 8.5 & 2.3 & 1.0 & 82.5 & 0.7 & 3.5 & 99.7 & 55.0 & 2380 \\
\hline
\end{tabular}

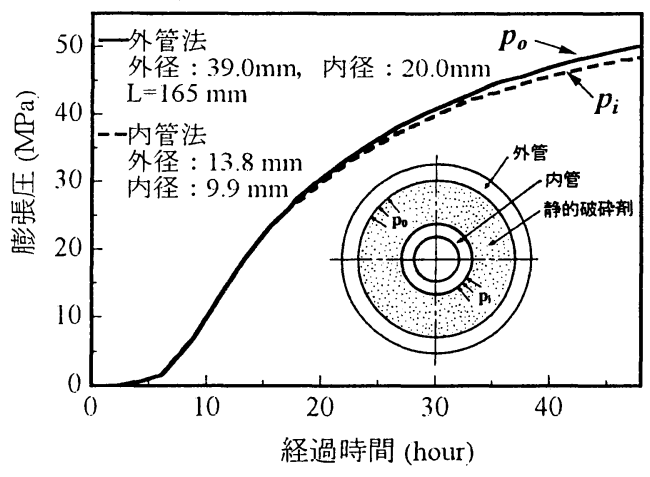

図一1 二重管試験に打けう膨張圧の経時变化

用も図られ，実用化されている 。 さらに，連続繊維 補強材の引張試験用の定着法としても利用でき, 文献 1 ) 中の連続繊維補強材の試験方法（案）の資料編に, 「I . 定着用膨張材を用いた引張試験方法」として掲 載されている.

\section{2. 定着法の発想と定着法の概要}

\section{（1）定着法の発想}

筆者らは，静的破硚剂を用いたコンクリートの破碑 に関する研究を行っている過程で, ボーリング孔中の 膨張压を直接測定する方法として内管法 ${ }^{8)}$ を考案した. この方法は内周面に直交ひずみゲージを貼付した鋼管 （内管）を充填孔中に挿人し，それに生じるひずみ值 より厚肉円筒理論式を用いて膨張圧を算定する方法で ある. 内管法についての検証, すなわち, 被破砕体に 作用している膨張圧をどの程度の精度で検出できるか を確認する目的で，鋼管（外管）の中に内管を挿入し て二重管とし，その間に静的破哗剤のスラリーを充填 して, 外管に作用する䐍張圧 $p_{0}$ と内管に作用する膨 張压 $p_{i}$ とを比較するいわゆる二重管試験を実施した. その結果，図一1に示すように経時変化にともなうp。 と $p_{i}$ は，ほぼ等しく作用することがわかった.このこ とは，内管に相当する王力計の形状が扁平であっても

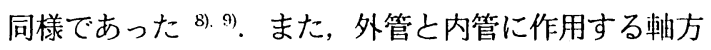
向力の和が, 膨張压と静的破砕剂断面積の積 $\left(p_{i} \cdot A_{k}\right)$ に等しくなることより, 軸方向へも半径方向と等しい 裝張圧が作用していることを確認した．以上のことよ

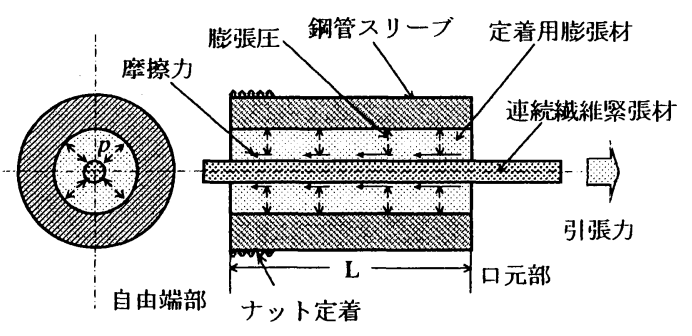

図一2 定着用膨張材を用いた定着体の概姴

り，膨張圧の伝播は液圧的であると見なすことができ る.

ところが，実験を終了して内管を取り出そうとした ときに，静的破哚剂の硬化体を少々除去したくらいで は内管は取り出せなかったのである，通常，鋼管に充 填された静的破砕剤を除去するには，ドリルやコアカ

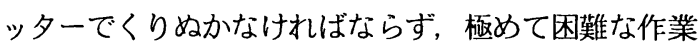
となる. 静的破砕剂は固体化し，さらに高膨張圧が作 用しているため当然の結果である.

さて, 液圧的な圧力伝播亡高膨張压の発生, しかも 取り出し困難な固体となる一連の現象を，直ちに連続 繊維緊張材の定着に利用しようと図ったわけではなか った．鉄筋継手への応用が，当初まず思い浮んだ発想 であったが, その後, 連続繊維補強材のコンクリート 構造物への適用に関する研究が各方面で進む中, その 定着方法が最大の難関であるとの話題に触発され，特 にせん断に弱い緊張材の定着には，液圧的澎張特性を 持つ静的破砕剤の逆利用こそ最適と直感し，二重管試 験における内管を連続繊維緊張材に置き捘える発想へ 移っていったのであった．本来「コンクリートを壊す」 目的で始めた研労に端を発して，「唋張材を定着する. 研究へ推移していった経緯は，このようにごく自然な 成り行きであった.

\section{（2）定着法の概要}

図一2に示すように，長さ $200 \mathrm{~mm}$ 程度の膨張王拘 束用スリーブ（鋼管，FRP 管等）の断面中央部に連続 繊維緊張材を挿人，セットする．スリーブと連続瀻維 緊張材との隙間に静的破哗剂または定着用膨張材を水 で練り混ぜたスラリーを充填する．スラリー状態から 数洔間媵には使化し, 常温では 48 時間後には $40 \mathrm{MPa}$ 


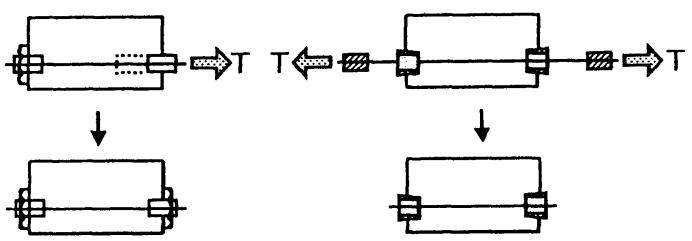

図一３緊張・定着方法

以上の高膨張圧が発生するため，スリーブと連続瀻維 緊張材が一体となった定着体が得られる. 以後, 定着 用膨張材を介し，スリーブと連続纎維緊張材が一体と なったものを「定着体」と呼ぶ。なお，スリーブ長さ 方向の膨張圧は, スリーブ両端部近傍を除いて一様に 作用することを確認している.

ここで，定着用膨張材と静的破砂剂の化学組成を比 較して表一 1 に示す. 両者とも膨張の主役は $\mathrm{CaO}$ で, 咭張圧の大きさや液圧伝播特性はほとんど同じである.

定着の基本原理は以下のようである.この定着体自 体をナット等で固定し, 連続繊維緊張材に引張力を作 用させた場合，高膨張圧によって緊張材と固体化した 定着用膨張材の接触面は，大きな付着強度を有するた めに引張力に抵抗できる. また, 緊張材の断面形状が 異型状であっても嘭張圧は液圧的に周囲から作用する ため，応力集中が少なく確実な定着が可能となる.し たがって，本定着法はスリーブの大きさを適当に選び さえすれば，ロッド，より線，板状など，その形状， 寸法, 䋐維の種類にかかわらず適用できる利点を有し ている.

定着方法には, 図一 3 に示す 2 通りの方法が考えら れ，便宜的に（Ｉ）法，（II 法と呼ぶことにする.

(I)法：一方の定着体をナットで固定し，もう一方 の定着体はカプラーに接続して唋張した後に, ナット で定着する方法である.

（II 法： 定着体とするスリーブを定着予定简所に予 めセットし固定しておく，連続繊維緊張材を挿入して 緊張し，仮定着を行う．その後，定着用膨張材スラリ 一を定着予定箇所に予めセットしたスリーブに充填す る. 所定の膨張圧に達した段階で緊張端の仮定着をゆ るめ，予めセットしておいた定着体に反力をとらせて 固定する方法である. この方法の特徽は, 連続繊維紧 張材が緊張された状態で膨張正が作用することにある. 本定着法の応用の一つに「中間定着工法」がある.

一般に，連続瀻維紧張材は鋼材に比へて仰びが大き く，（Ｉ）法では現場施工において，定着体自体に十 分な伸びしろをとる場合には定着体の長さが長くなり すぎるために，その解決方法の一つとして（II )法を考 案した.

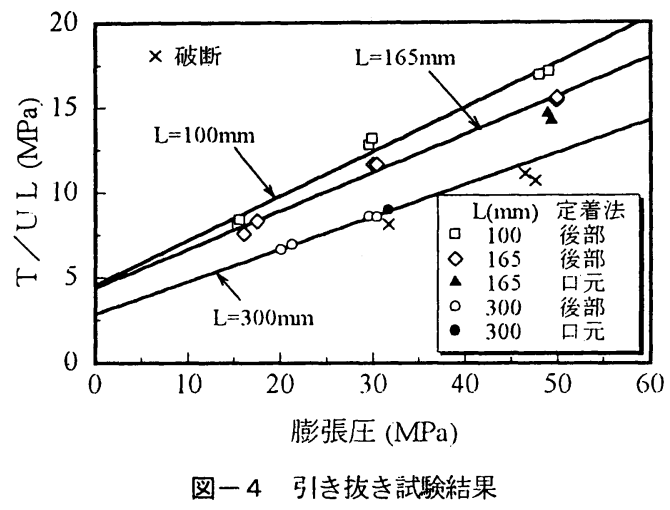

\section{3. 引き抜き試験}

定着体は図一2に示す構造であるため，連続䋐維緊 張材の破断荷重以下で，抜け出しや口元部分での緊張 材の破断等が生じないかを調べておく必要がある.

ここでは，定着体から抜け出さないための必要な膨 張圧, 定着長（スリーブ長）の関係を調べるために引 き抜き試験を実施した。

\section{（1）実験概要}

連続繊維緊張材の両端に定着体を設け，ナット定着 でアムスラー試験機にセットして, 引張試験の要領で 引き抜き試跧を奏施した，スリーブには，高㖣張圧に よって有害な変形を起こさない肉厚を有する鍋管を使 用した．外径 $39 \mathrm{~mm}$, 内径 $20 \mathrm{~mm}$ で, 内部には M22 ピッチ2 のネジを全長にわたって切り, 瑇部を設けて いる.これは，スリーブ内面と定着用裝張材の一体性 をより確実にするためのものである.

両端の定着体のうち，試験側では，スリーブ長を $100 \mathrm{~mm}, 165 \mathrm{~mm}, 300 \mathrm{~mm}$ とし, 膨張圧は $15 \mathrm{MPa}, 30 \mathrm{MPa}$, $50 \mathrm{MPa}$ を目安にそれぞれ変化させた場合について検討 した．膨張圧の管理は，鋼管スリーブ表面に直交方向 に貼付したひずみゲージの值より，式（1）を用いて 膨張圧 $\mathrm{p}$ を求める方法によった. 当然のことながら, もう一方の定着体からの引き抜けが先行しないように, スリーブ長を $300 \mathrm{~mm}$ とし, 試験特には哇張圧が $60 \mathrm{MPa}$ 以上になるようにした

$$
p=\frac{E_{s}\left(k^{2}-1\right)}{2\left(1-v^{2}\right)}\left(\varepsilon_{\theta}+v \varepsilon_{z}\right)
$$

ここに, $E_{s}$ : 鋼管スリーブの弾性係数

$k$ : 外内湰比 (外湰 内径)

$v$ : 鋼管スリーブのポアソン比

$\varepsilon_{t}$ : 䢹周方向ひずみ, $\varepsilon_{z}:$ 軕方向ひずみ 


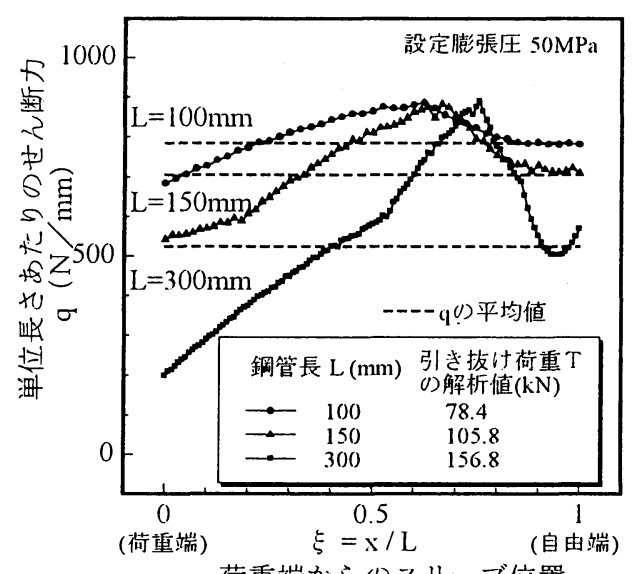

荷重端からのスリーブ位置

図一5 引き抜け荷重洔の単位長さ当たりのせん断力分布

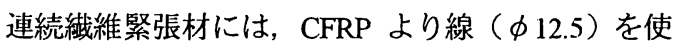
用した. アムスラー試験機のクリアランスの関係から, 連続繊維緊張材の全長は，鋼管スリーブ長さによらず $1.2 \mathrm{~m}$ とした，本実験では，引き抜け荷重まで漸増載 荷しながら，荷重はロードセルで，定着体荷重端側（以 後，口元部亡呼ぶ）における鋼管スリーブと CFRP よ り線との相対変位を $1 / 500 \mathrm{~mm}$ 精度のクリップ型变位 計によって，自由端変位は $1 / 1000 \mathrm{~mm}$ の変位計で測定 した.

\section{（2）実験結果と考察}

図一4に，引き抜け荷重（T）を鋼管スリーブ長（定 着用膨張材充填長 L)，CFRP より線（ $\phi 12.5 ）$ の有 効周長（U）で除した值 $\mathrm{T} / U L$ 之膨張圧（p）との関係 を示した．両者の関係は，L をパラメータとして，ほ ぼ直線で近似できる。従って夷験結果は，式（2） のような関係式で表すことができる.

$$
T=U L\left(\tau_{0}+\mu p\right)
$$

ここに, $\tau_{0}:$ 付着強度

\section{$\mu:$ 連続繊維緊張材と定着用膨張材との 摩擦係数}

図ー4中の定着法の「後部」および「口元」とは, ナットの定着位置による呼び方の略称である. すなわ ち，試験機に定着する特のナットの位真が，図一2に 示した定着体の自由端部であるものを「後部ナット走 着」と呼び，定着体口元部を直接アンカープレートに あてて反力をとらせるか，または口元部分でナット定 着する場合を「口元定着」と呵んでいる. 図一4では， 定着位置の違いが，引き抜け荷重に及ぼす影響は見ら れない．また同図では， $\mathrm{L}=165 \mathrm{~mm}$ の直線は $\mathrm{L}=100 \mathrm{~mm}$



$\begin{array}{ll}\text { (a) } \mathrm{L}=165 \mathrm{~mm} \text { の場合 } & \text { (b) } \mathrm{L}=300 \mathrm{~mm} \text { の場合 }\end{array}$ 図一 6 口元之自由端変位の挙動

の直線よりやや下方に位置している程度であるが, $\mathrm{L}=300 \mathrm{~mm}$ ではかなり下方に位置している. L が長く なるにつ机，直線は下方にシフトしており，この理 由は以下のように考えられる。

図一5は，鋼管スリーブと CFRP より線はともに弾 性要素とし, 定着用嘭張材を水平力を伝達する弾塑性 せん断ばね要素として連結させた有限要素モデル ${ }^{10)}$ 用い，引き抜け解析を行った結果の一例で，引き抜け 荷重時の単位長さ当たりのせん断力 $\mathrm{q}$ の分布を示して いる.q はスリーブ長さ方向の単位長さあたりのせん 断力であるので，スリーブロ元部分から自由端までの q の積分値は口元部に作用する引張荷重に等しくなる. 解析では, 荷重增分法により,この q の積分値が最大 になる洔点の荷重を引き抜け荷重 $\mathrm{T}$ とし，Lをパラメ 一タとして示した.この Tをスリーブ長 Lで割った T/L は q の平均値を表し，図一5の破線に相当する.ささら に緊張材の周長 U で割った T/UL は，スリーブ長さ方 向の平均付着応力を表すが，スリーブ長さ方向の平均 化という意味では，qの平均值と同様である. 従って, 実験結果は図一4のように T/UL で処理しているが, ここでは， $\mathrm{q}$ 分布ならびに $\mathrm{q}$ の平均值を用いて考察を 進めていくことにする.この解析における設定膨張田: は50MPa である.

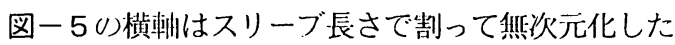
荷重端からのスリーブ位㯰を示している．スリーブ長 が 100 $\mathrm{mm}$ のように短い場合の q 分布は，引き拔け時 にはなだらかな分布で，平均值（破線）を表す一様分 布に置き換えが可能である.すなおち，スリーブ長が 短い場合には, 綮張材に作用する付着応力の平均值が, 
表 -2 長期載荷供試体水準

\begin{tabular}{|c|c|c|c|c|c|}
\hline 供試体 & 膨張材の種類 & $\begin{array}{c}\text { 鋼管刏-7゙長 (mm) } \\
\text { (有效)長) }\end{array}$ & $\begin{array}{c}\text { 最大緊張荷重 }(\mathrm{kN}) \\
\text { (仮緊張開放前) } \\
\end{array}$ & $\begin{array}{c}\text { 定着值後 (kN) } \\
\text { ( II 法定着時) }\end{array}$ & $\begin{array}{l}\text { 定着 } \\
\text { 方法 }\end{array}$ \\
\hline $\mathrm{A}$ & \multirow{3}{*}{$\begin{array}{c}\text { 静的破砕剂 } \\
\text { B- } 100 \\
W / B=25 \%\end{array}$} & \multirow[b]{2}{*}{$220(210)$} & 113.0 & 110.0 & I \\
\hline B & & & $\begin{array}{c}112.4 \\
(109.4)\end{array}$ & $\begin{array}{r}111.5 \\
(96.2) \\
\end{array}$ & II \\
\hline $\mathrm{C}$ & & $300(290)$ & 113.6 & 112.1 & \multirow{2}{*}{ I } \\
\hline $\mathrm{D}$ & \multirow{5}{*}{$\begin{array}{c}\text { 定着用膨張材 } \\
\text { A } \\
\text { W/B }=30 \%\end{array}$} & & 116.6 & 83.7 & \\
\hline E & & $220(210)$ & $\begin{array}{c}117.4 \\
(112.9)\end{array}$ & $\begin{array}{c}115.4 \\
(101.0) \\
\end{array}$ & II \\
\hline $\mathrm{F}$ & & $300(290)$ & 117.8 & 114.7 & \multirow{2}{*}{ I } \\
\hline $\mathrm{G}$ & & $220(210)$ & 83.6 & 77.5 & \\
\hline $\mathrm{H}$ & & $300(290)$ & $\begin{array}{c}116.3 \\
(112.6) \\
\end{array}$ & $\begin{array}{c}112.0 \\
(106.4)\end{array}$ & II \\
\hline
\end{tabular}

全体的にある付着応力の限界值に達した段階で引き抜 けるものと考えられる. 一方, $\mathrm{L}=300 \mathrm{~mm}$ の q 分布は, 全体的になだらかな分布ではなく，ピーク值が荷重端 からある位置に生じた状態で引き抜けると考えられる. $\mathrm{L}$ が長い場合には, 引き抜け機構が異なってくるので ある.このように $\mathrm{L}$ が長くなると q の分布は一様でな くなり，qの平均值は小さくなってくる. 上記は設定 膨張圧が $50 \mathrm{MPa}$ の場合であるが, 設定膨張圧が低い 場合には, それに対応して q の值全体が低下するので, スリーブ長 L をパラメータとして彭張圧に比例した直 線が得られる. 以上から，スリーブ長が長くなると, 図一40ように直線は下方にシフトするものと考えら れる. 今回の解析は, 図一 4 に示した実験值の定量的 評価を目的としたものではない. しかしながら，例え ば $\mathrm{L}=100 \mathrm{~mm}$ の場合, $\mathrm{q}$ の平均值は約 $800 \mathrm{~N} / \mathrm{mm}$ で，こ れを平均付着応力(T/UL)に換算すると $15.3 \mathrm{MPa}$ となっ て, 解析值は実験值よりやや低めではあるが, よい対 応を示している.

ところで, CFRP より線（ $\phi 12.5 ）$ の破断荷重 $165 \mathrm{kN}$ に対して, 定着に必要な膨張圧あるいは鋼管スリーブ 長を決定する方法は, 以下のようである. 式 (2) は, あらかじめ鋼管スリーブ長が決められた場合の $\mathrm{T}$ と の関係式であるので, 式 (2) に破断荷重 $\mathrm{T}=165 \mathrm{kN}$ を与えれば，定着に必要な澎張圧 $\mathrm{p}$ はただちに決定で きる. 例えば， L=165mm の場合には，図一4の実験 結果を最小自乗法により求め, $\mu=0.2 .3, \quad \tau_{0}=4.4 \mathrm{MPa}$ を得る.これを式 (2) に代人して, 必要膨張圧は $\mathrm{p}=64 \mathrm{MPa}$ を得る. $\mathrm{L}=300 \mathrm{~mm}$ の実験結果からは, $\mu=0.19$, $\tau_{0}=2.8 \mathrm{MPa}$ となり, 同様にして $\mathrm{p}=41 \mathrm{MPa}$ を得る. 当 然のことながら，スリーブ長が短い場合には，高い㣍 張压が設定されなければならない。

式（2）を他の種類あるいは径を有する連続䋊維祭 張材へ適用する場合には，実駼的に $\mu 、 \tau_{0}$ O)值を決め る必要がある. 例えば，アラミド組紐ロッド（ の場合, $\mathrm{L}=400 \mathrm{~mm}$ で $\mu=0.13, \tau_{0}=3.5 \mathrm{MPa}$ であった. 連続繊維緊張材を固めている樹脂量によっても表面の
付着性状に影響して $\mu, \tau$ 。の值は変動することが予想 されるので, 各種連続繊維緊張材ごとに, 種々の鋼管: スリーブ長 $\mathrm{L}$ に対する $\mu$ ， $\tau_{0}$ の值を実験的に求めて おけば, 式（2）により定着に必要な壯張圧を決定す ることができる.

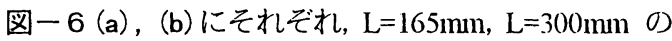
場合の引き抜けに至るまでの荷重亡変位の関係の一例 を示した．変位は， 口元部での鋼管スリーブと CFRP より線との相対変位 (口元変位) と自由端変位である. 口元変位は, 設定膨張圧が小さい方が, 荷重の小さい 段階から大きく出て引き抜けに至っている. 一方, 自 由端変位は，引き抜ける直前までほとんど変化してい

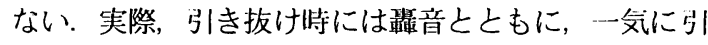
き抜けた．ただし，自由端部での CFRP より線の滑り 込み量は $15 \mathrm{~mm}$ 程度であった.

CFRP より線が破断に至る場合でも，破断荷重の70\% 程度の荷重での口元変位は 1 2 $\mathrm{mm}$ となっている. 口 元変位が生じることで，口元部での応力集中の緩和が 図られていると考えられる。

\section{4. 長期特性}

本定着法では，前述のように破断まで定着が良好な 場合でも，破断荷重の $70 \%$ 程度の荷重での口元変位は 1〜2mm であった. しかしながら，長期にはさらにそ の値が増大して，緊張力の低下を引き起こすことが紫 念されるため, 長期載荷実験を実施し, ポストテンシ ヨン工法の永久アンカーとしての長期特性について調 べることを目的としている.

\section{（1）供試体と実験方法}

実駼水準として，嘭張材の種類，定着方法の遌い， 鋼管スリーブ長，棌張力の大きさを取り上げ，表一2 に示す $\mathrm{A} \sim \mathrm{H}$ の 8 供試体とした．定着方法は，第 2 章 （2）で述べた（I）法，（II）法である.

（I）法供試体は，両定着体の憉張圧が 50MPa 以 


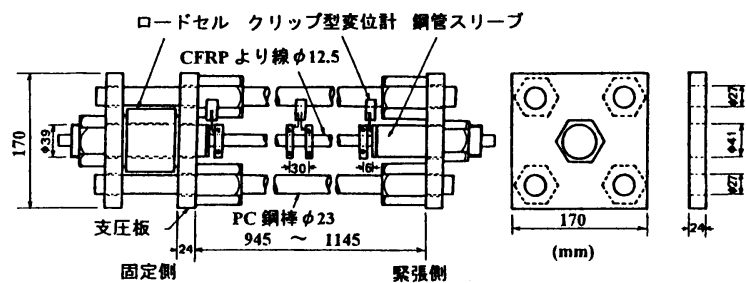

(a) I 法用

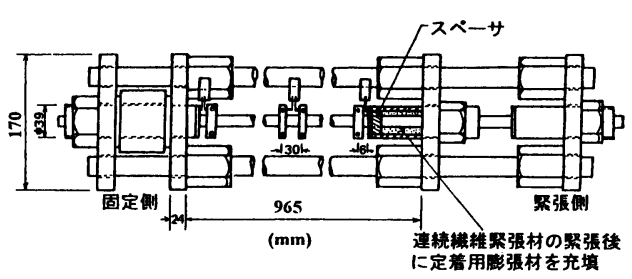

(b) II 法用

図一7 長期載荷用反力装置

上になった段階で，図一7（a）のような装置にセッ トし, 定着予定の荷重まで緊張, 除荷を 2 回繰り返し, 3 回目の緊張で緊張側の定着体をナット定着した.こ の緊張作業での, 最大緊張荷重とナット定着した直後 の荷重をそれでれれ「最大緊張荷重」，「定着直後」と して表一2に示した.

（II）法供試体は，図一7（b）のようにロードセ ル側を固定端として，緊張側の定着体を定着予定の荷 重まで緊張後, ナットで仮定着する. その後, 内側に セットした鋼管スリーブに定着用䐍張材を充填して, その膨張圧が 50MPa に達した時点で, 緊張側の仮定 着を徐々にゆるめ, 内側にセットした鋼管スリーブに 反力をとらせることによって定着が完了する.

いずれの場合も定着完了直後からの緊張力と口元変 位の経時変化を計測した．口元変位は，第 3 章で述へ たと同様,クリップ型変位計を用いて鋼管スリーブと CFRP より線に取り付けたアタッチメントとの相対変 位量を測定した. ただし，アタッチメント位置までの CFRP より線の変形量を CFRP より線中央部での測定 値を用いて補正した．鋼管スリーブ長は，第3 章 (2) の結果に基づき，両端部のスペーサの取り付け長を考 慮した $220 \mathrm{~mm}$ を基準とした. また，両端部のスペー サ分を除いて，定着用嘭張材が完全に充填される長さ を「有效長」として, 表一2のカッコ内に表示した. 緊張荷重は，破断荷重 $165 \mathrm{kN}$ の 70\%，50\%とした．両 定着体の口元間距離は，いずれも $800 \mathrm{~mm}$ である．実 験は, $25^{\circ} \mathrm{C}$ の恒温室で行った.

\section{（2）緊張力の経時変化}

（Ｉ）法では，上記のように2 段階の作業を行って いる. まず最初の仮緊張段階は（I）法之同じである ので,「最大緊張荷重」と「定着直後」の荷重か計測 される．次に，中間の定着体に充填された定着用膨張 材が 50MPa に達するまでに 48 時間程度要し，その間 「定着值後」の荷重は，表一2に示した「仮緊張解放 前」の荷重までやや低下する. さらに緊張側の仮定着
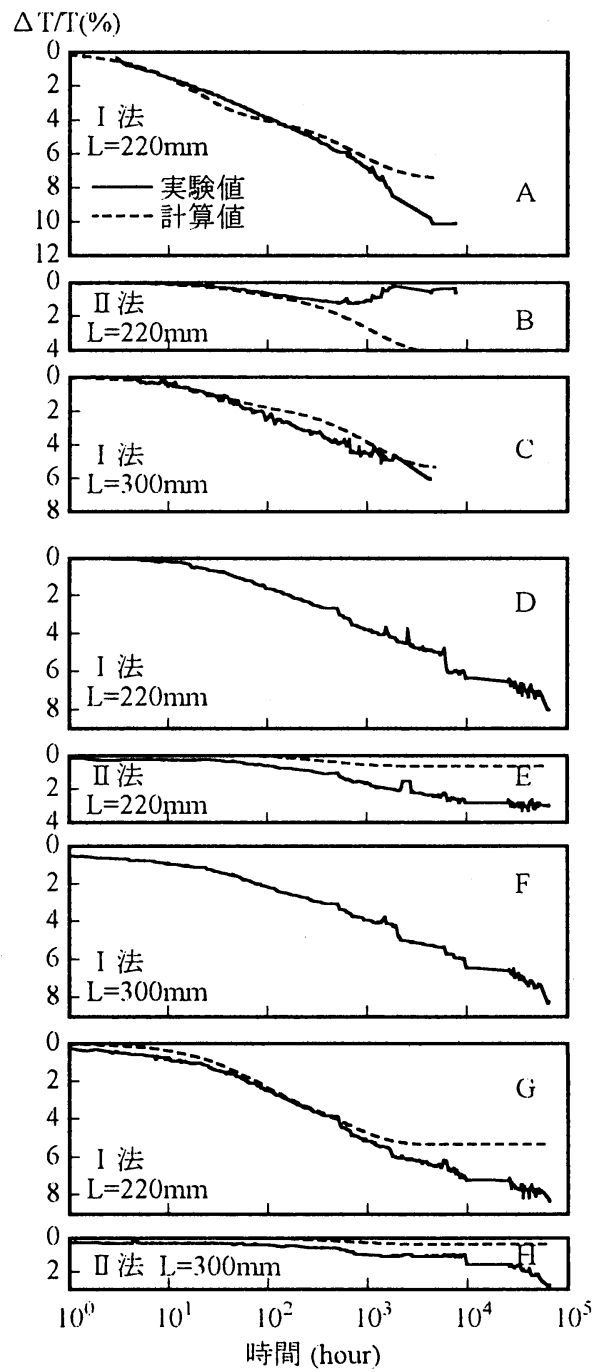

図一８緊張力低下の経時変化

を徐々にゆるめ, 最終的に中間の定着体に反力をとら せて定着が完了する時点までに（（II）法定着時）， 6〜13kNの緊張力のロスがみられる.これは, 反力プ 

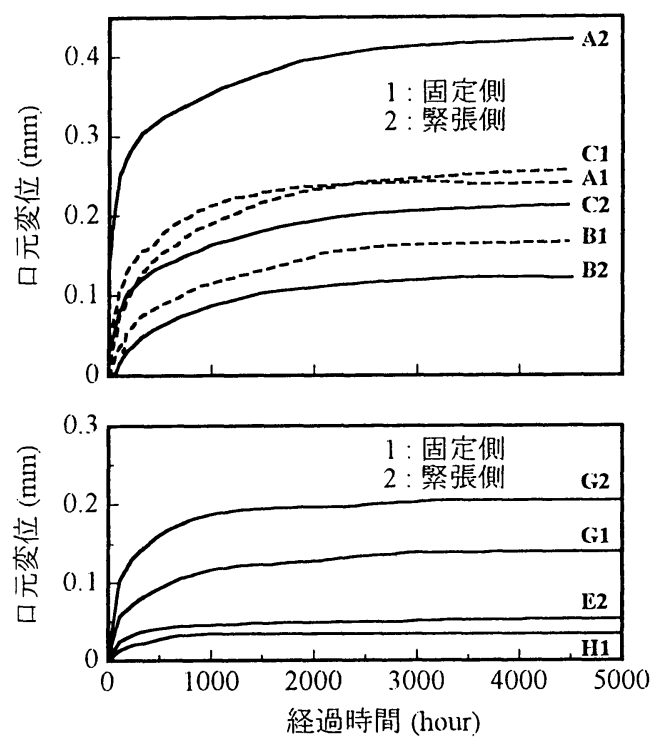

図ー9 口元変位の経時変化

レート,ナット間のなじみや弾性変形に起因するもの であり, 試験区間か短いために，わずかの变形でも䜿 張力のロスになったと考えられる.

図一8は, 緊張荷重低下率の定着完了直後からの経 時変化である. A C 供試体では，4500 時間までの 結果を，D〜Hについては65000 時間（約 7.4 年）ま での結果を示した.（I）法では $\mathrm{L}=220 \mathrm{~mm}$ の場合で 6 11\%，L=300mm の場合で 6〜8\%と鋼管スリーブ 長による顕著な差は見られない，（Ｉ）法に比へ，（II ) 法による定着を行った供試体 $\mathrm{B} ， \mathrm{E} ， \mathrm{H}$ では，さらに 小さくなっており，Hでは 3\%である.これは，緊張 した状態で哇張圧が作用しているため, 仮定着解放時 の CFRP より線のポアソン效果が加わって, より強固 な定着になっているためと考えられる.

\section{（3）緊張力の減少と口元变位の関係}

ここでは，緊張力の低下が生じる主たる要因は口元 変位であると考え，以下のような検討を行った．口元 変位の長期における経時変化の代表的な例を図一9に 示す.

口元変位. $\mathrm{u}$ の経時変化は，式（3）で近似できる.

$u(t)=\beta_{1}\left(1-\exp \left(-t / k_{1}\right)\right)+\beta_{2}\left(1-\exp \left(-t / k_{2}\right)\right)$

ここに, $\beta_{1}, \beta_{2}, \mathrm{k}_{1}, \mathrm{k}_{2}$ は最小自乘法によって決ま る実験定数

いま, 口元変位を一種のクリープ変形とみなして,

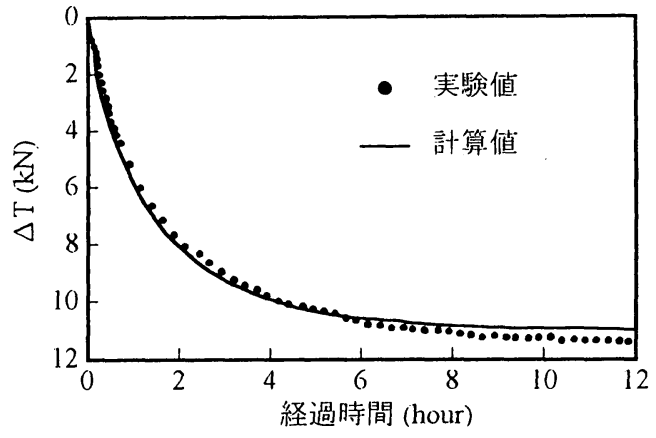

図一 10 (a) D 供試体の緊張力低下の経侍泌化

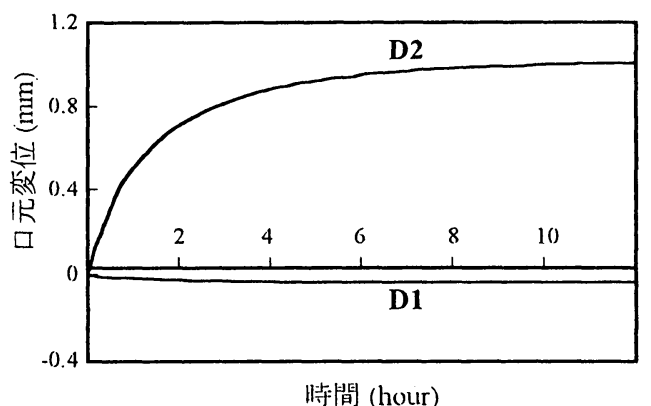

図一 $10($ b) D) 供試体O)口元変位 0 )経時変化

時刻 $\mathrm{t}$ から $(\mathrm{t}+\mathrm{dt})$ までの微小時間内に生じる変形に ついて考える. dt 時間に反カフレームと緊張材は同一 変形を行うという適合条件と力のつりあいより, 緊張 力のロス量 $\Delta \mathrm{T}$ に関して次のような微分方程式を得る.

$$
\frac{d \Delta T}{d \phi_{1}}+\alpha \Delta T-\alpha T_{0}=0
$$

ここに, $\quad \phi_{1}(\mathrm{t})=\left(\mathrm{u}_{1}(\mathrm{t})+\mathrm{u}_{2}(\mathrm{t})\right) \quad\left(\mathrm{T}_{0} \mathrm{~L} / \mathrm{E}_{\mathrm{p}} \mathrm{A}_{\mathrm{p}}\right)$

$\mathrm{u}_{1}(\mathrm{t}), \mathrm{u}_{2}(\mathrm{t})$ : 固定侧, 浆張側の口元変位

$\mathrm{T}_{0}$ : 定着直後の初期緊張力

L:緊張材の長さ

$\mathrm{E}_{\mathrm{p}} \mathrm{A}_{\mathrm{p}}$ : 緊張材の弓張剛性

$\alpha$ : 反力フレームと緊張材の換算断面積比

初期条件として $\mathrm{t}=0$ ) で, $\Delta \mathrm{T}=0, \phi_{1}=0$ とおいて, 式 (4) の解を求めると次式を得る.

$$
\Delta T / T_{0}=1-\exp \left(-\alpha \phi_{1}\right)
$$

D供試体は 3 回目の奖張時, 定着直萠の $119 \mathrm{kN}$ で 緊張侧から抜け出しが生じたので, 直ちに定着を行っ て, 緊張力と口元変位の経時変化を計測した. 定着直 後から 12 時間までの緊張力と口元変位の経時変化を 図一10 (a)，(b)に示す. 12 時間までの口元変位の 経归変化を式（3）で近似し，式（5）に代入して計 


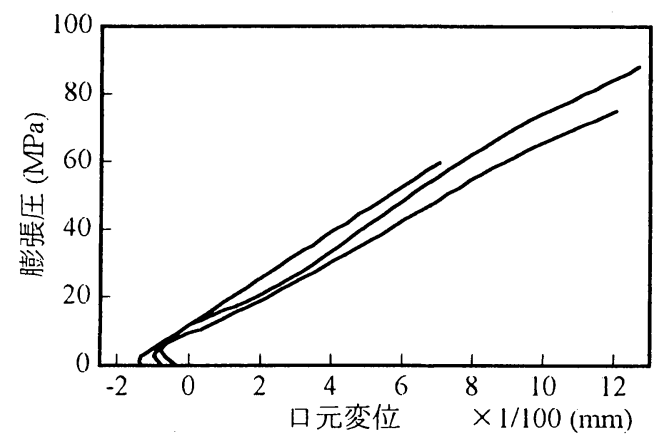

図-11 膨張压と口元変位の関係

算した緊張力の経時変化曲線は, 実験結果とよく合致 していることがわかる.この例からも口元変位の挙動 之緊張力の減少の挙動が対応していることがわかる.

なお，図一8に示した長期の緊張力の変化は，12 時 間後に緊張力が $84 \mathrm{kN}$ でほぼ安定した時点を初期緊張 力としている.

同様に，長期における緊張力の低下も主として口元 変位に起因して生じると考えられる.ここでは, 図一 9 に示した 4800 時間までの口元変位の実測值を式 （3）で近似し，式（5）を用いて緊張力の減少の経 洔変化を計算した結果を図一8に破線で示した．口元 変位の計測が行われた時点までの緊張力の変化は, 計 算結果と実験結果は比較的よく合致している. 式 (3) は，時間が十分に経過すれば，ある值に収束する関数 であるので，緊張力低下の計算値も十分に時間が経過 した時点で収束している. 緊張力の低下の要因として, 口元变位の影響が支配的亡考えられるが, 㛑張材自体 のレラクセーションの影響も考慮すれば，より実際の 緊張力の低下曲線に合致するものと考えられる.なお， $\mathrm{D}$ 供試体と $\mathrm{F}$ 供試体については，長期計測途中での変 位測定の不具合により, 計算結果は割愛した。

\section{（4）緊張力の低下に及ぼす膨張圧の影響}

上記から緊張力の減少は, 主に口元変位の進行が影 響していることがわかった．この口元変位を進行させ る要因の一つに, CFRP より線の軸方向に作用する膨 張圧の影響が考えられる.

図ー 11 には 220 mm の鋼管の中央に CFRP より線 を立てた状態で，定着用膨張材を充填して，澎張圧之 口元変位の関係を示した．膨張圧が発生する前のスラ リ一状態時, CFRP より線の自重による沈下で負の方 问へ变位しているが，緊張力の作用していない状態で も牂張圧の增加に伴って口元変位が増加していること がわかる.このことより，膨張圧が增加する限り口元 変位は進み，緊張力が低下することになる，逆に，膨 張圧の增加が減少すれば，緊張力は安定すると思われ

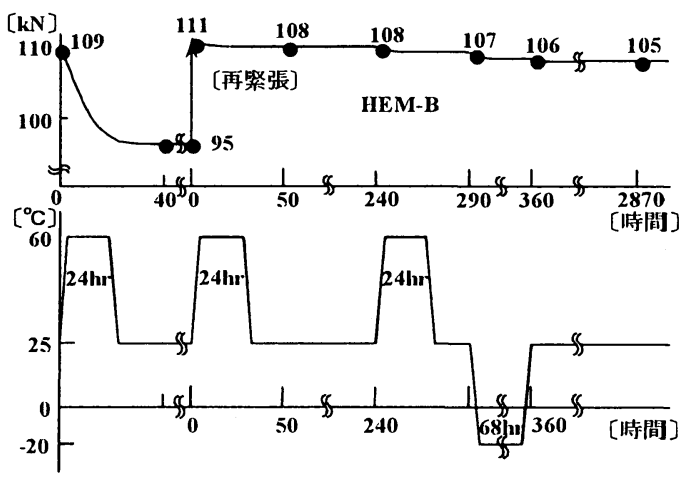

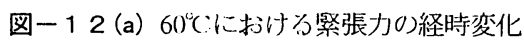

$[k N]$

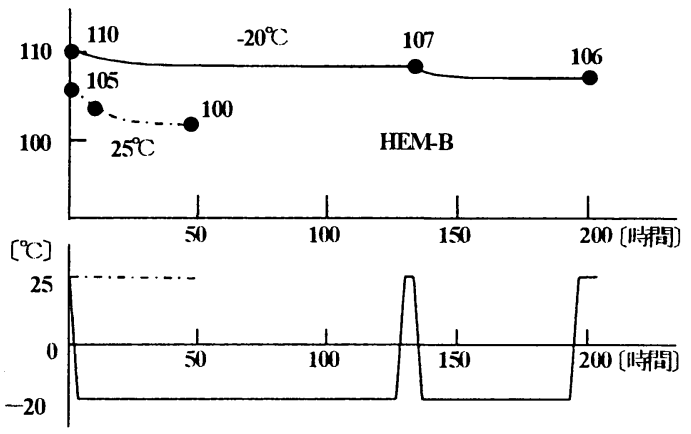

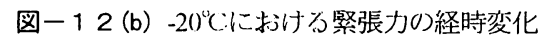

れる.

彫張圧の発生は, 水和反応によるもので, 温度が高 くなれば反応が活性化して膨張圧が大きく出る.また, 定着用膨張材自身その高浢張压を受けており, 傩張力 が作用した状態では軸方向へのクリープ変形も大きく， 緊張力に影響を及ぼすものと推察される. そこで, 水 和反応の程度が極端な $2 つ 0$ 場合を設定した実験を行 った．実験装置は，図一7 (a) と同様で, 口元変位の 影響が大きく出るように CFRP より線の試験区間を $300 \mathrm{~mm}$ と短くし, $115 \mathrm{kN}$ の緊張力で定着した. 緊張 力の測定は， $25^{\circ} \mathrm{C}$ 状態で行った. 図一 12 (a)，(b) は, 緊張力変化と温度変化を対応させて示した. 同図 より, 以下のことがいえる.

○図ー12 (a)では，緊張定着後直ちに $60^{\circ} \mathrm{C}$ 環境 下に置き，24時間後の緊張力の低下準は $12.7 \%$ 之

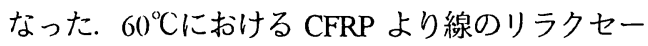
ヨン率 $2.5 \%$ "1)を引けば, $10.2 \%$ となる. 以後, $60^{\circ} \mathrm{C}$ 24 時間の状態を 2 回履歴させ, 完全水和に近い 状態での緊涱力の低下率は $2.4 \%, 0.6 \%$ とほとん どなくなっている. 初期に緊張力の低下率が大き いのは, $60^{\circ} \mathrm{C}$ 環境下で膨張圧が急激に增加した ためであり，2回目以降は膨張圧の增加がほとん ど起こらないため低下率が小さいと考えられる. 


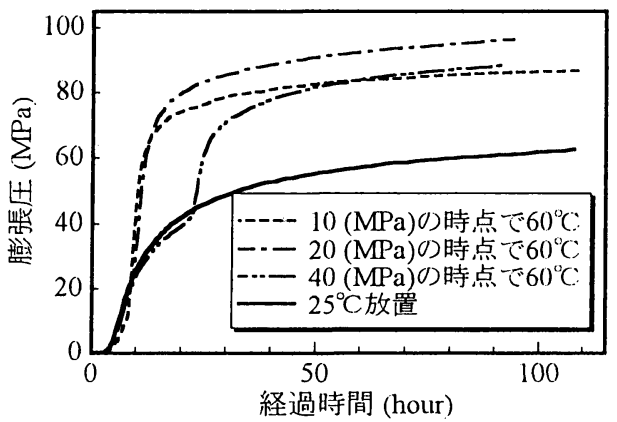

図一 $1360^{\circ} \mathrm{C}$ 環境設定侍期と膨張圧の挙動

○緊張定着後直ちに- $20^{\circ} \mathrm{C}$ 環境下に置き, 水和反 応を遅らせた場合の低下率は, $25^{\circ} \mathrm{C}$ 場合より小 さく, $2 \%$ 以下であった.

以上の結果は, 水和反応の進行状態亡緊張力の低下 とは，密接な関係があることを裹付けている. 澎張圧 の増加がなくなって一定値になれば，緊張力も安定す るといえよう。なお，緊張力の変化之膨張圧の変化の 直接的な関係でなく，上記のような間接的な評価とせ ざるを得なかった理由は，緊張状態にあり，しかも温 度変化を伴う場合の供試体自体の膨張圧計測は，ひず みゲージその他の方法でも困難であるからである.

図一 13 には, 図一 12 (a)に関連して, 膨張圧の 温度変化による特性の一例を示す. すへてての供試体を まず $25^{\circ} \mathrm{C}$ 恒温室で充填し，それぞれ 10MPa，20MPa， $40 \mathrm{MPa}$ の洁張圧に達した時点で, $60^{\circ} \mathrm{C}$ の環境下に置 いた場合の膨張压の経時変化である. いずれも $60^{\circ} \mathrm{C}$ の環境下に置いた時点から膨張圧は增加するが，水和 反応がある程度進んだ 40MPa の場合は伸びがあまり 大きくない．20MPa の場合が最も膨張圧が最も大き く出ている. 10MPa の場合は, 初期の増加率は極め て大きいが，長期における增加率が小さい。これより， 膨張圧を大きく効果的に出すための適当な時期がある ということがわかる.

さて，上.記のように試験区間が $300 \mathrm{~mm}, 800 \mathrm{~mm}$ と 短い場合で，緊張力の低下が大きいものでも $10 \%$ 程度 であった. 例えば, 初期緊張力を上記実験と同じ $110 \mathrm{kN}$, 緊張定着後の経時変化にともなう口元変位を両端部合 わせて $3 \mathrm{~mm}$ と大きめに仮定し, 緊張材長が $10 \mathrm{~m}$ とし て式 ( 5 )によって計算した場合, 緊張力の低下は $2.8 \%$ となる. 実用上は，緊張材長がさらに長くなることを 考慮すれば，無視しうる大きさといえよう。

\section{（5）長期膨張圧と定着用膨張材の耐久性}

永久アンカーとして, 嘭張圧が長期において低下す ることはないか，また定着用膨張材の化学的な步化は， 問題ないのかという点が重要である. 図一80ように,

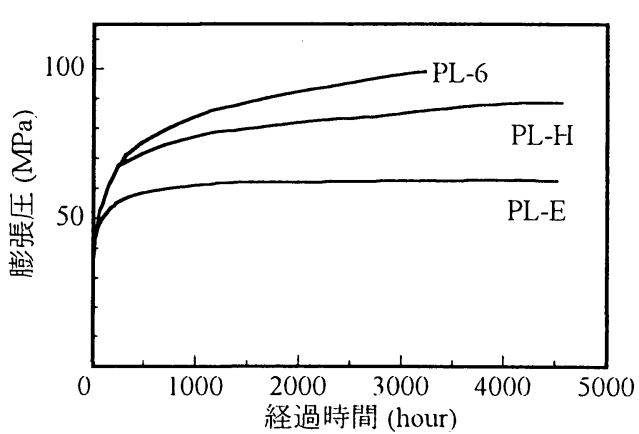

図ー144500特間までの洁張压の経時変化

\begin{tabular}{|c|c|c|}
\multicolumn{2}{c}{} & \multicolumn{2}{c|}{ 表 $-3 \quad$ 長期膨張圧 } \\
\hline 供試体 & $\begin{array}{c}\text { 膨張压 } \\
(\mathrm{MPa})\end{array}$ & $\begin{array}{c}\text { 充填後 } \\
\text { 経過日数 }\end{array}$ \\
\hline B-100 & 95.4 & 800 \\
\hline B-150 & 110.7 & 1050 \\
\hline HEM-B-1 & 90.8 & 1174 \\
\hline HEM-B-2 & 91.8 & 1174 \\
\hline
\end{tabular}

載荷開始から約 7.4 年が経過していても祭張力の低下 が数\%という結果からは，長期には問題ないといえそ うであるが，ここでは，長期における膨張压の特性之 スリーブ端部からの中性化の影響について述べる.

図一 14 は，長期載荷試験に使用したのと同様の鋼 管スリーブに充填した定着用嘭張材の 4500 時間まで の膨張圧の経時変化の一例である．膨張圧は徐々に増 加するかあるいは安定しており，低下はみられない．

また，表一３は鋼管スリーブに充填した定着用咭張 材をコアカッターでくり抜き，鋼管表面のひずみ值か ら作用膨張圧を算定する， いわゆる応力解放法により 求めた結果である. 充填後およそ 1000 日での䛧張圧 は90〜100MPa である.ここで，使用した定着用膨張 材之嘭張主成分量がほぼ同じである静的破砤剤の彭張 圧 $\mathrm{p}(\mathrm{MPa})$ 之水和洠 $\mathrm{h}(\%) 0$ 関係は，式（6）のように 近似できることが隼者らの研究でわかっている”.

$$
p=129(h / 100-0.14)^{1.68}
$$

この式より，水和率 $100 \%$ での膨張圧を推定すると 100MPa となって, 表一3の結果は, 完全水和に近い 状態と考えられる．定着用膨張材はセメント硬化体組 織と同様の組織を有する固体であって，膨張成分が完 全に水和するまで洁張は継続すると考えられる．定着 用膨張材自身その高膨張圧を鋼管スリーブから常寺反 力として受けており，それに抵抗しながら徐々に嘭張 することによって膨㖘圧をさらに増加させ，より緻密 な硬化体組織になっていくものと推察される ッ.12) 定 着用膨張材の水和反応は，セメント之同様に長期に緗 続しており，鋼管スリーブの拘束状態か湾化しない限 
表-4 疲労坛输結果一筧

\begin{tabular}{|c|c|c|c|c|c|c|}
\hline 記号 & 膨張材の種類 & $\begin{array}{c}\text { 設定膨張圧 } \\
(\mathrm{MPa})\end{array}$ & $\begin{array}{c}\text { 上限荷重 } \\
(\mathrm{kN})\end{array}$ & $\begin{array}{c}\text { 下限荷重 } \\
(\mathrm{kN})\end{array}$ & $\begin{array}{l}\text { 繰り返し回数 } \\
\text { (回) }\end{array}$ & $\begin{array}{c}\text { 疲労試謳後 } \\
\text { 破断荷重 }(\mathrm{kN})\end{array}$ \\
\hline B-F1 & \multirow{2}{*}{$\begin{array}{l}\text { 静的破砕剂 } \\
\mathrm{W} / \mathrm{B}=25 \%\end{array}$} & \multirow{5}{*}{50} & 117.7 & 88.3 & $200 \times 10^{4}$ & 154.0 \\
\hline B-F2 & & & 132.4 & 98.1 & $200 \times 10^{4}$ & 162.8 \\
\hline HEM-A-F 1 & \multirow{3}{*}{$\begin{array}{c}\text { 定着用膨張材 } \\
\text { HEM-A } \\
\text { W/B }=30 \%\end{array}$} & & 132.4 & 98.1 & $200 \times 10^{4}$ & 162.8 \\
\hline HEM-A-F2 & & & 141.2 & 127.5 & $205 \times 10^{4}$ & 疲学破断 \\
\hline HEM-A-F3 & & & 132.4 & 117.7 & $500 \times 10^{4}$ & 141.2 \\
\hline HEM-B-F1 & \multirow{5}{*}{$\begin{array}{c}\text { 定着用䞘張材 } \\
\text { HEM-B } \\
\text { W/B }=27.5 \\
(\%)\end{array}$} & \multirow{3}{*}{100} & 132.4 & 98.1 & $210 \times 10^{4}$ & 168.7 \\
\hline HEM-B-F2 & & & 142.2 & 122.6 & $210 \times 10^{4}$ & 162.8 \\
\hline HEM-B-F3 & & & 117.7 & 78.5 & $150 \times 10^{4}$ & 疲労破断 \\
\hline HEM-B-F4 & & \multirow[b]{2}{*}{50} & 142.2 & 121.6 & $200 \times 10^{4}$ & 166.7 \\
\hline HEM-B-F5 & & & 133.4 & 85.3 & $200 \times 10^{4}$ & 163.8 \\
\hline
\end{tabular}

りこれまで彭張して緻密になった硬化体組織は保持 されると考えられる．この状態で，自らの膨張压によ って生じるクリープ変形は極めて小さく，したがって， 長期における膨張压の低下は起きないと考えている.

次に，定着用膨張材の耐久性のうち，中性化につい て実験的に検証した代表的な結果について述べる。こ れは，定着用膨張材の反応は， $\mathrm{CaO}$ が水和し $\mathrm{Ca}(\mathrm{OH})_{2}$ が生成する反応であるため，コンクリートと同様に中 性化することが考えられ，無拘束状態に近く外気にさ らされるスリーブ雨端部分においては, 組織の脆弱化 と中性化による膨張圧の低下が長期的には懸念される からである.ここでは，両端部からの内径 $20 \mathrm{~mm}$ ，長 さ $200 \mathrm{~mm}$ の鋼管に定着用唼張材（W/B=27\%）を充填 し, $20^{\circ} \mathrm{C}$ 気中に 1 週間放置後, 両端部での定着用膨張 材の自由澎張による脆弱部を除去したままの供試体と， 除去部にパテ状エポキシ接着剤でシーリングした供試 体を，中性化促進試験装置に入れ， $\mathrm{CO}_{2}$ 浱度 $5 \%$ ，温 度 $20 \pm 1^{\circ} \mathrm{C}$, 湿度 $60 \%$ にて暴露を行った. シーリング なしの場合で， 12 ヶ月後の中性化澡さは平均 $2.2 \mathrm{~mm}$ とわずかであった．エポキシ樹脂でシーリングした場 合の中性化樑さは $0 \mathrm{~mm}$ であった. このことより，エ ポキシ樹脂等で端部のシーリングを施せば，中性化は 生じないものと思われる.

\section{5. 疲労特性}

\section{（1）実験方法}

ここでは，引張疲労試験により定着具の疲労性状に ついて検討する．鋼管スリーブ長は，すべて $220 \mathrm{~mm}$ （有効充填長 $210 \mathrm{~mm}$ ）とした. 緊張材には CFRP よ り線（ф12.5）を用い，両端の定着長を含めた全長は 720mm である. 供試体 HEM-B-4, HEM-B-5 の 2 体の み CFRP より線の試験区間長が 1000mm である.

繰り返し速度は $2.5 \mathrm{~Hz} \sim 4 \mathrm{~Hz}$ とした. 下限荷重は, 保証破断荷重 $142 \mathrm{kN}$ の $60 \%$ 以上とし，荷重振幅は， 榎本之白鳥によって報告されている疲労酎久線図 ${ }^{13)}$ もとに, CFRP より線が疲労破壊せずにかつ定着体に
できるだけ負荷のかかるよう設定した. より線の場合， 引張荷重の增加にともなって，よりが戻る方向にねじ りモーメントが発生し，それが度労試験機のアクチュ エータの回転を起こさせ，早期に破断することがある. 本疲労試験においては, 疲労試験機のアクチュエータ の回転を防止するために，より戻り防止治具を取り付 けた.

所定の繰り返し回数每に試験機を止め，4.9kN から 上限荷重まで静的に載荷し，上下定着体口元間の変位 量（ $\delta ）$ を計測した. $4.9 \mathrm{kN}$ は初期設定荷重である. 疲労試臨の開始は，膨張圧が $50 \mathrm{MPa}$ 以上に達した時 点を標準に, 100MPa の場合も設定した.これは膨張 圧が最終的には 100MPa 程度に達し，高彭張压なるが 故に，几元部での材料の破断が䘗念されるからである.

\section{（2）実験結果と考察}

供試体と実跧結果一覧を表一 4 に示す。一体は 205 万回で，他の一体は 200 万回に達する以前に CFRP よ り線の疲学破断を起こしたが, 定着部口元部分からの 破断ではなかった，CFRPより線が破断すれば，バラ バラになって破断箅所の特定は難しいが，引張破断し た简所は繊維がほうき状になることで破断筒所を推定 している.

図一15 (a)，(b)には，上限荷重時，下限荷重時に おける上下定着体の口元間における変位量（雨端部か らの抜け出し量の総和）それぞれについて, 各繰り返 し回数ごとの変化を示した. 上限荷重が大きい方が口 元変位量も大きくなっている. 繰り返し回数とともに 口元変位は徐々に增加しているが，図一15 (a)にお いて上限荷重 $141 \mathrm{kN}$ の場合で, 200 万回後の変位の増 加量は $0.8 \mathrm{~mm}$ とわずかであった．また，設定膨張王 が 100MPa のほうが，50MPa の場合より，口元変位は 小さめにでていることがわかる.

HEM-A-F3 は，定着用膨張材の耐候性の検詂も目的 として, $60^{\circ} \mathrm{C}$ (46恃間) $\Rightarrow 110^{\circ} \mathrm{C}(24$ 時間 $) \Rightarrow$ 炉内除冷 （96 時間） $\Rightarrow-20^{\circ} \mathrm{C}(160$ 恃間 $) \Rightarrow 110^{\circ} \mathrm{C}(48$ 洔間 $) \Rightarrow$ 炉 内除冷(18 時間) 之過酷な環境下においた後に疲労斌 


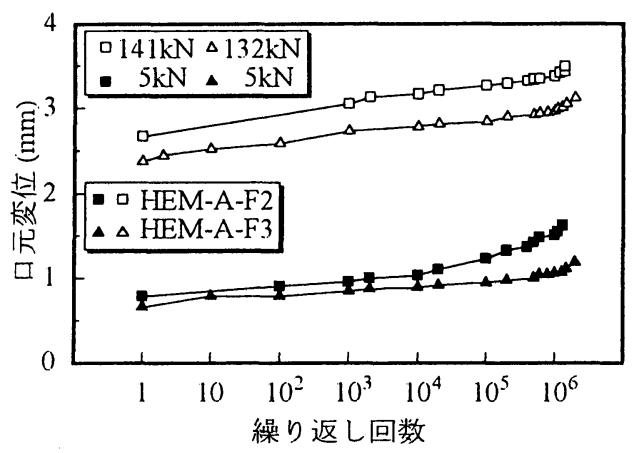

（a）設定彫張压 50MPa の場合

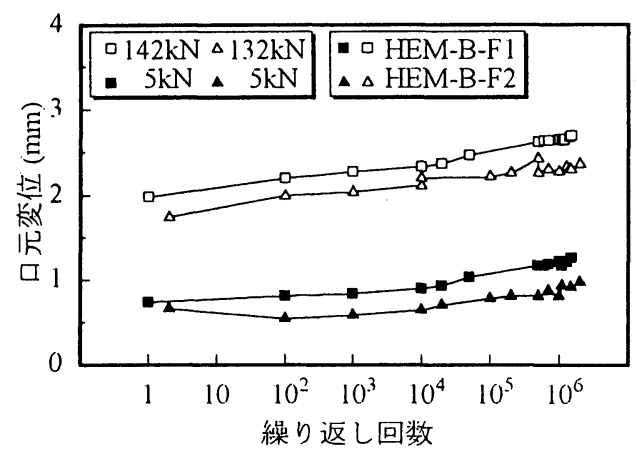

（b）設定膨張压 $100 \mathrm{MPa}$ の場合

図一15 各繰り返し回数毎の口元変位の変化

験を実施した，上記のような温度環境条件の設定を行 ったのは, 定着用膨張材の耐久性に温度変化が最も撖 しい影響を与えると考えたからで，現実の温度履歴よ りも䈌しい条件を設定した. 500 万回繰り返し後にお いても， 口元部分からの CFRP より線の異常な抜け出 しや，定着体自体の異常は見られなかった，疲労試験 後の静的引張試験において, 過酷な壊境条件下に放置 後 500 万回繰り返した HEM-A-F3 では, 破断荷重が $14 \mathrm{kN}$ とやや低めの保証破断荷重程度となっているが, 他の供試体では, 疲労試験前の引張強度との有意な差 は見られない，破断箇所はいずれも定着体口元部以外 であった.

図一-16は表 -4 の疲労試験結果に基づき，応力振 幅と平均応力との関係をプロットしたものである. 実 構造物, 例えば外ケーブル方式やアンボンド方式の定 着具として使用する場合には, 通常, 緊張応力は保証. 破断荷重の 60\%（約 $1100 \mathrm{~N} / \mathrm{mm}^{2}$ )，活荷重による変動 応力は高々 $25 \mathrm{~N} / \mathrm{mm}^{2}$ 程度亡見積もられるので, 今回 の疲労試験で設定した平均応力, 応力振幅の組み合わ せほどの大きな繰り返し荷重は作用しないことになる. したがって, 定着用膨張材を用いた定着法（HEM 定 着法）による定着部の疲労は笑用上, 問題にならない と思われる。

ここでは，外ケーブル方式やアンボンド方式の定着 具として使用するための疲労安全性の検討を主目的亡 していたが，上記の結果から，むしろ HEM 定着法を 連続繊維補強材の引張疲労試験の定着具として積極的 に活用することが考えられる，HEM 定着法による CFRP より線 $(\phi 12.5)$ の引張疲労試倹のデー夕は, 現在, いくつかの研究機関で蓄積されつつある.

一方, メーカーは CFRPより線の定着部分となる端 部のよりをほどき，鋼管スリーブに拆人してエポキシ 樹脂で固定した定着法（樹脂定着）で，引張疲労試験 を実施している. 図一16 に示した実線は, 樹脂定着

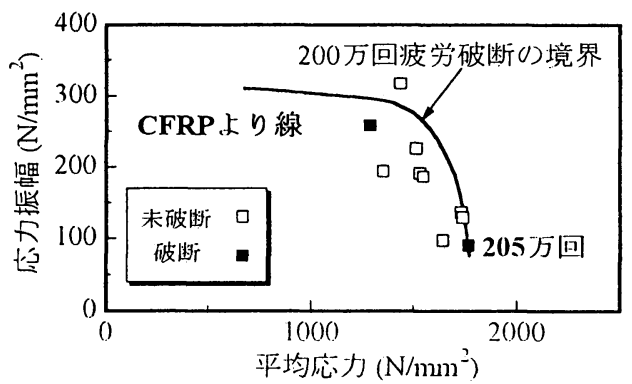

图-16 応与振幅一平均応力で表した疲労試跧結果

による CFRP より線（ $\phi 12.5 ）$ の疲労耐久線図 ${ }^{13)}$ であ る. すなわち，笑線より上の領域では繰り返し回数 200 万回以内で疲労破断が生じることを意味している。樹 脂定着法と HEM 定着法それぞれによる疲労試験結果 を図ー16に示す応力振幅一平均応力関係で比較した ところ, 静的引張試呀では，定着法の違いによる破嵝 荷重に差がほとんどないにもかかわらず，HEM 定着 法の方が, CFRP より線（ かに向上するという結果が得られている ${ }^{10)}$ ．樹脂定着 の場合には，200 万回以前に，ほぼ確㿤に渡労破断を 起こす平均応力と応力振幅の組み合わせにおいても, HEM 定着では CFRP より線は疲労破断しないのであ る.すなわち，図一160実線が上方にシフトするの である.このことは, CFRP より線 ( $\phi 12.5)$ 以外O 連続繊維補強材ではまだ確認していないが, 定着方法 の違いが連続纎維補強材の疲労特性に及ぼす影響につ いては，たいへん興味ある内容であり，今後追蒊して いきたいと考えている.

\section{6. マルチケーブル用定着体}

斜張橋のケーブルのように緊張力の大きな場合やグ ラウンドアンカー工法, 通常のPC工法においてもマ ルチケーブル方式は多用されている．定着用膨張材に 


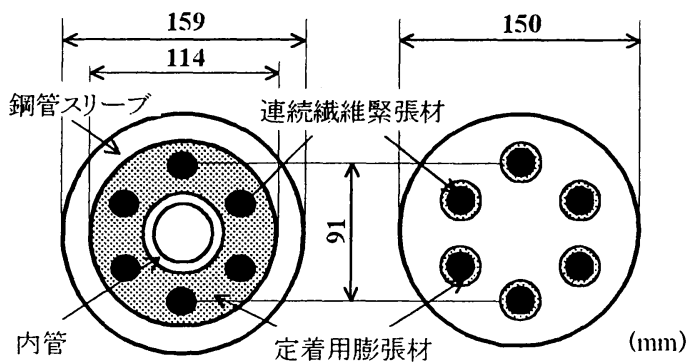


図一17 マルチケーブル配置 (Aタイプ)

よる定着法のメリットの一つは，このマルチケーブル 配置が容易にできる点である．ここでは，CFRP より 線（ $\phi 12.5 ） 6$ 本を用いる場合（緊張容量 600kN クラ ス）を対象とし，検討した結果について述べる.

\section{（1）マルチケーブル配置}

緊張材の配置は, 図一17 (a), (b) と図一18(a), (b)のようなものが考えられる. 図一17 (a)では, 中 央の中望部分は，テンションバーを通すスペースであ ると同時に，定着用膨張材の断面積が大きくなること にともなう水和熱の急激な温度上昇を抑制する目的の ために設けた．図一17 (b) は，シングル配置を基本 として䅉成され, 緊張材 1 本每に定着用膨張材の充填 スペースか確保されている．いずれも実施工を考虑し て，横向きに置いた状態で定着用膨張材の充填が行え る実用性の高い充填方法を考案し，またその充填作業 性のよいことも確認している.

図一18 (a)，(b)は，䋜張材をコンパクトにまとめ るという観点での配置形である. 図一 18 (b) の配置 は, 現在，グラウンドアンカー【法 ${ }^{(0)}$ の定着体として 使用されている。

一般に，定着用嘭張材を用いるマルチケーブルの定 着体スリーブは，定着用膨張材が十分に充填できるだ けのスペース，すなわち緊張材相互の間隔，スリーブ

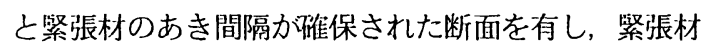
が1本の場合と同じ定着長のスリーブでよいと考えて いる.これまでの経験から，相互のあき間隔は $3 \mathrm{~mm}$ 程度確保されれいば, 充填性, 定着ともに十分であると 思われる. ただし，䋈張材の周長の合計よりスリーブ 内面の周長の方が小さい場合には，スリーブ内面と定 着用膨張材の界面でのすべりが起きる可能性があるの で, スリーブ内面に凹凸の㩐を設ける等の対策が必要 である. コンパクトタイプПでは，スリーブ内面に凹

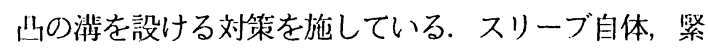
㖘荷重と版張圧に対して，有害となる变形や破損を起

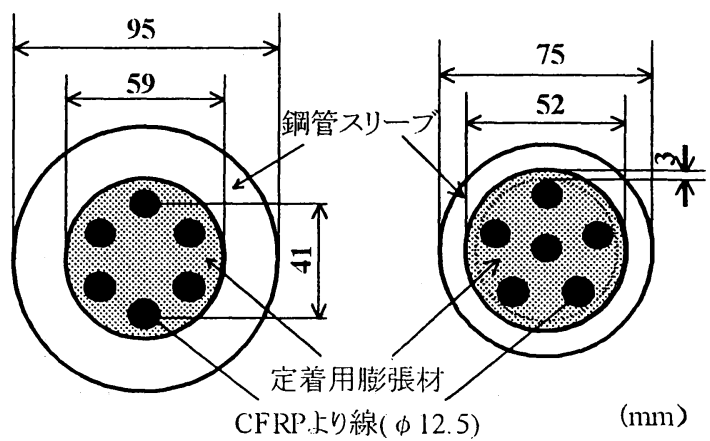
(a) コンパクトタイプI
(b) コンパクトタイプ II

図一-18 マルチケーブル配置 (B夕イプ)

表一5 マルチタイプの破断荷重

\begin{tabular}{|c|c|c|c|}
\hline 供試体 & $\begin{array}{c}\text { 破断行重 } \\
(\mathrm{kN})\end{array}$ & $\begin{array}{l}\text { マルチケーナ゙N } \\
\text { 配置状態 }\end{array}$ & 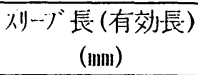 \\
\hline A-1 & 939 & $\mathrm{~A}-(\mathrm{a})$ & $300(250)$ \\
\hline A-2 & 916 & $A-(a)$ & $300(250)$ \\
\hline B-1 & 905 & B-(a) & 350 \\
\hline B-2 & 908 & B-(a) & 250 \\
\hline NM-1 & 9() 0 & $\mathrm{~B}-(\mathrm{b})$ & $4(1)$ \\
\hline NM-2 & 95.3 & B-(b) & 400 \\
\hline NM-3 & 952 & $B-(b)$ & 400 \\
\hline
\end{tabular}

こさない断面，材質のものを使用しなければならない のは当然のことである.

\section{(2) 引張試験結果と考察}

表一5に; CFRP より線（ $\phi 12.5 ） 6$ 本マルチの場 合の静的破断荷重を示す．表中のマルチケーブルの配 置状態を表す記号 A-(a)は図一 17 (a)に, B-(a)と B-(b) はそれぞれ図ー18 (a)，(b)に相当する．供試体の全 長は定着体部分の長さを含めて, $\mathrm{A}$ 供試体と $\mathrm{B}$ 供試体 で $2 \mathrm{~m}$, NM供試体で $2.5 \mathrm{~m}$ である. 破断荷重は, CFRP より線（ $\phi 12.5 ） 1$ 本の破断荷重 $162 \mathrm{kN}$ の 6 倍の $972 \mathrm{kN}$ よりやや低いものの, ほぼマルチ本数倍の破断荷重で 破断したとみることができる. 通常, マルチケーブル では, 各々のケーブル長さの違いが各ケーブル間の溸 張力差をもたらし, 最も拏張力の高いケーブルが先に 破断してしまい, 破断荷重が 1 本の破断荷重のマルチ 本数倍をかなり下回ることがあり, 祭張材か短いとそ れが特に顕著となる. 定着用澎張材による定着の場合, ほぼマルチ本数倍の破断荷重で破断しているのは, 各 ケーブルの緊涱力差が生じにくいためと考えられる.

図ー19は，A-2 供試体における各ケーブルの荷重 分担率と実引張荷重の関係を示した。この供試体のケ 一ブル全長は，両端の定着体を含めて $2 \mathrm{~m}$ と比較的に 短いために, 各緊張材長のアンバランスは, 荷重分担 率に顕著に現れると考えられる.ここでの荷重分担率 は, 各ケーブルに貼付したひずみゲージのひずみ值か ら計算した紧張力をその持点の載荷荷重で除した偲と 


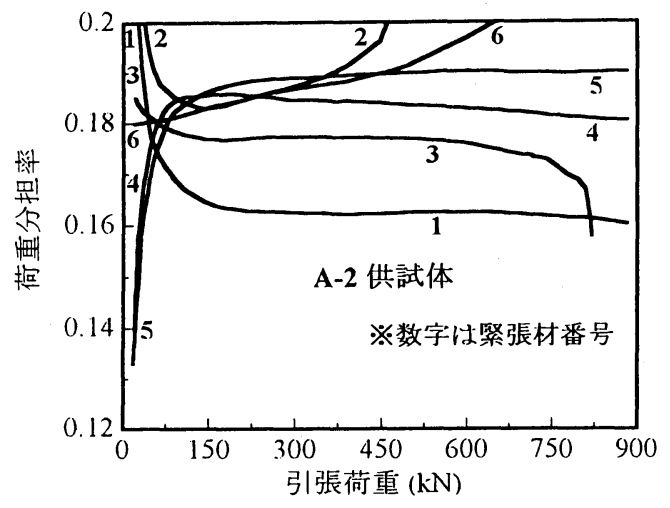

図一19 各緊張材の荷重分担率

した.これは他のケーブルのひずみ値に関係なく，各 ケーブル単独で荷重分担率が算定できるからである. ただしこの手法ではひずみの測定精度に依存するた め, 荷重分担率の総和が必ずしも 1 にならない場合も あるが，各緊張材の荷重分担率の相対比較という観点 からは，十分に評価できるものと考えている. 同図か ら, 載荷荷重の增大にともなって, 各ケーブルの荷重 分担率が互いに近づき，均等化するような挙動をして いることがわかる.

図一6で示したように，破断荷重の 70\%程度で 1 $2 \mathrm{~mm}$ の口元からの抜け出しがあることがわかる.す なわち, マルチの場合, 荷重負担の大きなケーブルで は口元部分からの抜け出しがおこり，これによってケ 一ブル長の初期不整は, ある程度吸収され得るもの之 考えられる. したがって，各ケーブルの荷重分担率は 均等になり，ほぼマルチ本数倍の破断荷重で破断する ものと考えられる.

口元部分からの抜け出しは，スリーブ全体におよぶ ものでないことは，図一20から明らかである. 口元 から $75 \mathrm{~mm}$ 位置の鋼管スリーブひずみは，直線から次 第にそれており, 引張荷重 700kN あたりでピーク値を 示している.これは, CFRP より線と定着用膨張材と の界面ですべりか起こりはじめ，CFRP より線からス リーブへのせん断伝達が十分に行われなくなったため と考えられる。これに対し，他の位置では破断までひ ずみがほほ直線的に挙動しているのは，これらの位犆 では CFRP より線と定着用澎張材との付着が十分に保 たれているために，CFRPより線に作用する荷重は， 定着用膨張材によって十分にせん断伝達され, 鋼管ス リーブが負担しているからだと考えられる。.

なお，図ー20に示した鋼管スリーブのひずみ挙動 は，緊張材が 1 本の場合之同様の挙動 ${ }^{10)}$ で，あたかも マルチケーブル全体がまとまって, シングルケーブル のように挙動しているように思われる。これは前述の

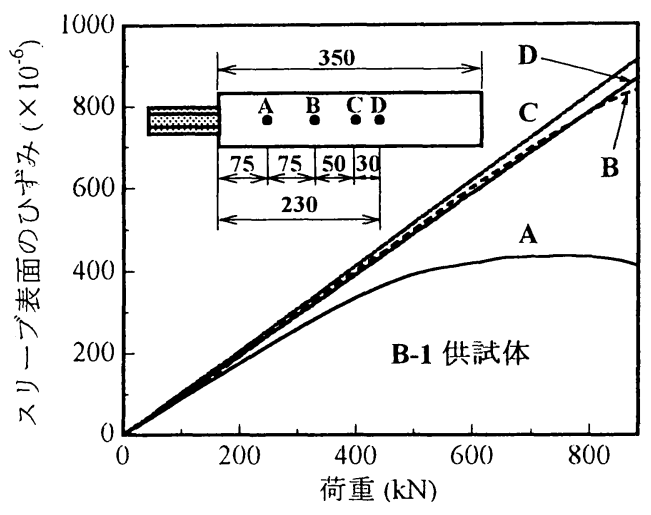

図ー2 O 鋼管スリーブ表面各点のひずみ変化

各ケーブルの荷重分担が，より均等化する挙動とも符 合する.

\section{7. 結論}

連続㵶維緊張材の新たな定着方法として, 定着用膨 張材を用いる方法を開発し，主として CFRP より線を 用いたポストテンション工法の永久定着法として用い るための基礎的な検討を行った. 本研究の䇛囲で得ら れた結果を列挙する.

（1）引き抜き試験の結果, 引き抜き荷重, 膨張圧之 鋼管スリーブ長の関倸は, $\mathrm{T}=\mathrm{UL}\left(\tau_{0}+\mu \mathrm{p}\right)$ なる 関係式が得られた。これにより, 定着に必要な 膨張圧，鋼管スリーブ長を算定できる.

（2）定着方法には（I）法, （II）法があるが, 絮 張した状態で定着する（II）法では, 長期の綮 張力のロスが,（I）法に比べて少ない.

（3）緊張力のロスは, 口元変位の挙動と対応してお り, 口元変位は膨張压の挙動と関係しているこ とがわかった. 膨張圧の增加を安定させれい゙， 緊張力のロスも小さくなる.

（4）65000)時間0長期載荷実験の結果，3〜11\%0緊 張力のロスが見られるが, 試験区間が $80 \mathrm{~cm}$ と 短い場合である. 口元変位量が同じとして, 緊 張材長が $10 \mathrm{~m}$ と長くなくなれば, 緊張力の口 スは，実用上は無視できる大きさとなる.

（5）鋼管スリーブ0ように拘束か確保されておけば, 長期膨張圧の減少はなく，100MPa 程度の膨張 圧となる. また, 両端部をエポキシ樹脂等でシ ーリングすれば，中性化は起こらない。

（6）実用上問題となるよりはるかに大きな応力振幅 一平均応力での疲労試鈳を奏施したが, 定着部 には買常は見られなかった. むしろ, 各種連続 䋐維補強材の疲労試験用定着具としての活朋を 
推奨したい.

（7）マルチケーブル配置は，大きな自由度をもって 設定でき, 引張試験の結果, 破断荷重は CFRP より線 1 本のマルチ本数倍に近い值であった. これは緊張力の均等化が, 口元変位が生じるこ とで自動的に行われているためと考えられる.

謝辞: 本研究は, 文部省科学研究買 (一般研觉 (C) 課題番号:05650437, 基盤研觉（C）（2）課題番 号:10650452）の一部により行ったものである.ここ に，付記して感謝の意を表します.

また，材料の提供等でご協力をいただいた（株）小 野田，東京製綱（株）に厚く御礼申し上げます。

\section{参考文献}

1) 土木学会 : 連続緎維補強材を用いたコンクリート構造物 の設計・施工指針 (案)，コンクリートライブラリ一第 88 号, 1996.

2）原田哲夫, 出光隆, 渡辺明, 高山俊一: 静的破砕剂を用 いた FRP 緊張材の定着法, プレストレストコンクリート の発展に関するシンポジウム論文集, pp.251-256, 1990).

3) 原田哲夫, 山崎竹博, 出光 隆: 定着用膨張材を用いた FRP 緊張材アンカーの長期および疲労特性, 連続䋞維補強材 のコンクリート構造物への適用に関するシンポジウム誨 演論文報告集，コンクリート技術シリーズ $1 ， \mathrm{pp} .223$ 228,1992.

4) Tetsuo Harada, Takashi Idemitsu, Akira Watanabe, Myo Klin and Koichi Soeda: New FRP Tendon Anchorage System Using Highly Expansive Material for Anchoring, Proceedings of FIP Symposium '93, Kyoto, Vol. II, pp.711-718, 1993.

5）原田哲夫，ミョーキン，樋野勝已，徳光 卓 : 定着用版張 材を用いた速続䋞維緊張材マルチケーブルの定着法, 第
3 回プレストレストコンクリートの発展に関するシンポ ジウム論文集, pp.285-290, 1992.

6)（財）土木研究センター：土木系材料技術・公募型技術審 查証明 報告書 NMグラウンドアンカー, 1994.

7) 渡辺泰行, 菊地秀二, 長橋弘和, 中島規道: 中間定着工 法の開発とその施工, プレストレストコンクリート, Vol.40, No.3, pp.26-30, 1998.

8）原时哲夫, 出光隆, 渡辺明: 静的破哗剂を用いたコン クリートの解体に関与る基礎的研究，土木学会論文集, 第360)号, V-3, pp.61-70, 1985.

9）原田哲夫, 副田炎一, 出光隆, 渡辺明: 静的破砕剂の 膨張压測定法之膨張压の諸性質, 土木学会論文集, 第 478 号, V-21, pp.91-100, 1993

10) Tetsuo Harada, Masashi Soeda, Tsuyoshi Enomoto, Suguru Tokumitsu, Myo Khin and Takashi Idemitsu: BEHAVIOR OF ANCHORAGE FOR FIRP TENDONS USING HIGHLY EXPANSIVE MATERIAL UNDER CYCLIC LOADING, Non-Metallic (FRP) Reinforcement for Concrete Structures, Proceedings of the Third International Symposium, ICI, Vol.2, pp.719-726, Oct., 1997.

11) 伊藤幸雄, 丸山武彦, 白鳥信令, 榎本 剛 : より線型 CFRP ロッドのリラクセーション特性, 上木学会第 45 回年次誨 演会請演概要集，第5 部, pp.322-323, 1990 .

12) 副田孝一, 原田哲夫 : 静的破砕剂の膨張圧発生機楎に関 する-考察, 土木学会諭文集, 第 466 号, V-19, pp. 89-96, 1993.

13) 榎本 風, 白鳥信命 : 炭絜絨維複合材料ケーブル(CFCC) の引張疲労特性, 土木学会第 45 回年次講演会㹃演概要集, 第 5 部, pp.324-325, 1990)

(1998. 8. 28 受付)

\title{
A STUDY ON ANCHORAGE METHOD FOR CONTINUOUS FIBER REINFORCING MATERIALS (FRP) USING HIGHLY EXPANSIVE MATERIAL
}

\author{
Tetsuo HARADA, Takashi IDEMITSU, Myo Khin, Koichi SOEDA \\ and Akira WATANABE
}

\begin{abstract}
It is of utmost importance to hold the FRP rods/strands when they are to be used as prestressing tendon or in tension tests. The authors have developed a new anchoring method. using Highly Expansive Material (HEM) in which the expansive pressure can be attained up to more than 50MPa and the pressure is transmitted in a manner similar to that of the fluid pressure. In this paper, the relationship between the anchorage length and the expansive pressure for post-tensioning type anchors. along with long term stability and fatigue characteristics and some others are investigated. Also supplemented with experimental studies on performance of multi-cable type anchorage.
\end{abstract}

